\title{
Antioxidant and cytotoxic activities of Dendrobium moniliforme extracts and the detection of related compounds by GC-MS
}

\author{
Mukti Ram Paudel ${ }^{1}$, Mukesh Babu Chand ${ }^{1}$, Basant Pant ${ }^{2}$ and Bijaya Pant ${ }^{1 *}$ (D)
}

\begin{abstract}
Background: The medicinal orchid Dendrobium moniliforme contains water-soluble polysaccharides, phenanthrenes, bibenzyl derivatives, and polyphenol compounds. This study explored the antioxidant and cytotoxic activities of $D$. moniliforme extracts and detected their bioactive compounds.

Methods: Plant material was collected from the Daman of Makawanpur district in central Nepal. Plant extracts were prepared from stems using hexane, chloroform, acetone, ethanol and methanol. The total polyphenol content (TPC) in each extract was determined using Folin-Ciocalteu's reagent and the total flavonoid content (TFC) in each extract was determined using the aluminium chloride method. The in vitro antioxidant and cytotoxic activities of each extract were determined using DPPH (2,2-diphenyl-1-picrylhydrazyl) and MTT (3-(4,5-dimethylthiazol-2-yl)-2,5-diphenyltetrazolium bromide) assays respectively. Gas chromatography and mass spectrometry (GC-MS) analysis was used to detect bioactive compounds.

Results: TPC content was highest (116.65 $\mu \mathrm{g} \mathrm{GAE} / \mathrm{mg}$ of extract) in D. moniliforme chloroform extract (DMC) and TFC content was highest (116.67 $\mu \mathrm{g} \mathrm{QE} / \mathrm{mg}$ of extract) in D. moniliforme acetone extract (DMA). D. moniliforme hexane extract $(\mathrm{DMH})$ extract showed the highest percentage of DPPH radical scavenging activity (94.48\%), followed closely by D. moniliforme ethanol extract (DME) (94.45\%), DMA (93.71\%) and DMC (94.35\%) at $800 \mathrm{\mu g} / \mathrm{ml}$ concentration. The antioxidant capacities of DMC, DMA, DMH and DME, which were measured in $\mathrm{IC}_{50}$ values, were much lower $42.39 \mu \mathrm{g} / \mathrm{ml}, 49.56 \mu \mathrm{g} / \mathrm{ml}, 52.68 \mu \mathrm{g} / \mathrm{ml}$, and $58.77 \mu \mathrm{g} / \mathrm{ml}$ respectively than the $\mathrm{IC}_{50}$ of $\mathrm{D}$. moniliforme methanol extract $(\mathrm{DMM})(223.15 \mu \mathrm{g} / \mathrm{ml})$. DMM at the concentration of $800 \mu \mathrm{g} / \mathrm{ml}$ most inhibited the growth of HeLa cells (78.68\%) and DME at the same concentration most inhibited the growth of U251 cells (51.95\%). The cytotoxic capacity $\left(\mathrm{IC}_{50}\right)$ of DMM against HeLa cells was $155.80 \mu \mathrm{g} / \mathrm{ml}$ of extract and that of DME against the U251 cells was $772.50 \mu \mathrm{g} / \mathrm{ml}$ of extract. A number of bioactive compounds were detected in both DME and DMM.
\end{abstract}

Conclusion: The fact that plant extract of D. moniliforme has a number of bioactive compounds which showed antioxidant and cytotoxic activities suggests the potential pharmacological importance of this plant.

Keywords: Dendrobium moniliforme, DPPH, GC-MS, HeLa cell line, MTT, U251 cell line

\footnotetext{
* Correspondence: bijayapant@gmail.com

${ }^{1}$ Central Department of Botany, Tribhuvan University, Kirtipur, Kathmandu,

Nepal

Full list of author information is available at the end of the article
}

(c) The Author(s). 2018 Open Access This article is distributed under the terms of the Creative Commons Attribution 4.0 International License (http://creativecommons.org/licenses/by/4.0/), which permits unrestricted use, distribution, and reproduction in any medium, provided you give appropriate credit to the original author(s) and the source, provide a link to the Creative Commons license, and indicate if changes were made. The Creative Commons Public Domain Dedication waiver (http://creativecommons.org/publicdomain/zero/1.0/) applies to the data made available in this article, unless otherwise stated. 


\section{Background}

Dendrobium is the second largest genus of the family Orchidaceae. There are 30 species in Nepal, distributed from tropical to temperate climatic regions [1]. It is an epiphytic orchid which is widely used in traditional medicine as a tonic and for treating human disorders [2-5]. One species of Dendrobium, Dendrobium moniliforme (synonym $D$. candidum), is a valuable medicinal orchid found across southeast and south Asia [1, 6, 7]. It contains water-soluble polysaccharides $[8,9]$, phenanthrenes, bibenzyl derivatives, and polyphenolic compounds [10-15].

Natural antioxidants and plant-derived compounds provide a strong defense against cellular damage caused by free-radical induced oxidative stress [16, 17]. Freeradicals and various reactive oxygen species are produced during cellular metabolism in all living systems and are responsible for oxidative cellular damage in human beings. To reduce this damage, some sort of defense mechanism is needed, and indeed, several types of natural and artificial antioxidants are used to control oxidative stress. In particular, plant-derived compounds are a potent source of novel antioxidant activity [18]. Bibenzyl derivatives isolated from $D$. moniliforme were examined for their antioxidant capacity using $\mathrm{DPPH}$ free-radical scavenging assay $[11,13,14]$, a popular tool because of its simplicity and high sensitivity. This assay works on the principle that any hydrogen donor is an antioxidant. Thus, a compound's antioxidant effect is proportional to the disappearance of $\mathrm{DPPH}$ radicals in test samples [19].

The natural antioxidant-rich compounds of $D$. moniliforme engage in many biological activities, including promoting the production of body fluids, serving neuroprotective, immunomodulatory and antioxidant functions $[2,20]$. D. candidum has previously been shown to have in vitro anticancer effects on human carcinoma cells [21-27]. Indeed, it is often the case that bioactive agents of folk medicine help prevent the development of cancer by inducing apoptosis [28]. The induction of apoptosis in cancer cells is initially identified by morphological changes, including cell shrinkage, membrane blebbing, chromatin condensation, and nuclear fragmentation. The MTT assay can be used to screen the cytotoxicity of a crude extract [29]. More specifically, GC-MS can be used to detect and identify bioactive compounds in crude extracts [30, 31].

Despite the potential of $D$. moniliforme, little information exists on the antioxidant and cytotoxic activities of the crude extract of this orchid. To remedy that gap, the present study explored the antioxidant and cytotoxic activities of crude extracts of the plant and detected bioactive compounds present in it.

\section{Methods}

\section{Plant material and the preparation of extract}

The stems of Dendrobium moniliforme were collected from Daman of Makawanpur district in central Nepal. The plant was identified by Dr. Keshav Raj Rajbhandari. A voucher specimen of this plant is deposited in the Tribhuvan University Central Herbarium (TUCH) (voucher number - M02). The collected stems were air-dried and powdered. A Soxhlet extraction was used to prepare plant extracts with solvents of increasing polarity: hexane, chloroform, acetone, ethanol and methanol in the ratio of 1:10 $(w / v)$ [32]. The solvents were then evaporated at room temperature to obtain dry extract and the extract was stored at $4{ }^{\circ} \mathrm{C}$.

\section{Determination of the total polyphenol content in extract} The total polyphenol content (TPC) in each extract was determined using the Folin-Ciocalteu's reagent method [33]. The reaction mixture was prepared by mixing $0.5 \mathrm{ml}$ of a stock solution of extract, $2.5 \mathrm{ml}$ of $10 \%$ Folin-Ciocalteu's reagent, and $2.5 \mathrm{ml}$ of $7.5 \% \mathrm{NaHCO}_{3}$. In tandem, a blank solution was prepared from $0.5 \mathrm{ml}$ of ethanol, $2.5 \mathrm{ml}$ of $10 \%$ Folin-Ciocalteu's reagent and $2.5 \mathrm{ml}$ of $7.5 \% \mathrm{NaHCO}_{3}$. The reaction mixtures were then incubated at room temperature for $45 \mathrm{~min}$ and their absorbance was measured using a Genesys UV-visible spectrophotometer at $765 \mathrm{~nm}$. The TPC in extract was expressed as micrograms of gallic acid equivalent (GAE) per milligrams of dry extract.

\section{Determination of the total flavonoid content in extract}

The total flavonoid content (TFC) in each extract was determined using the aluminium chloride method [33]. The reaction mixture was prepared by mixing $1 \mathrm{ml}$ of a stock solution of extract and $1 \mathrm{ml}$ of $2 \% \mathrm{AlCl}_{3}$. In tandem, a blank solution was prepared by mixing $1 \mathrm{ml}$ of ethanol and $1 \mathrm{ml}$ of $2 \% \mathrm{AlCl}_{3}$. The reaction mixtures were incubated for an hour at room temperature and then their absorbance was measured using a Genesys UV-visible spectrophotometer at $415 \mathrm{~nm}$. The TFC in extract was expressed as micrograms of quercetin equivalent (QE) per milligrams of dry extract.

\section{Evaluation of the antioxidant activity of the extracts}

The in vitro antioxidant activity of the extracts was determined using a DPPH (2,2-diphenyl-1-picrylhydrazyl) free-radical scavenging assay according to the method described in previous publication [34]. The stock solution of extract was diluted to prepare a series of concentrations (50, 100, 200, 400 and $800 \mu \mathrm{g} / \mathrm{ml}$ ) for the antioxidant assay. An aliquot of $1.5 \mathrm{ml}$ of $0.25 \mathrm{mM}$ DPPH solution in ethanol and $1.5 \mathrm{ml}$ of extract at each of the various concentrations was mixed. The mixture was shaken vigorously and allowed to sit for $30 \mathrm{~min}$ reach a steady state at room temperature. The 
decolourization of DPPH was determined by measuring the absorbance at $517 \mathrm{~nm}$ using a Genesys UV-visible spectrophotometer. The percentage of DPPH freeradical scavenging activity of each extract was then calculated using the following equation:

$$
\text { Scavenging rate }=\left[1-\left(\mathrm{A}_{1}-\mathrm{A}_{2}\right) / \mathrm{A}_{0}\right] \times 100 \%
$$

Where; $\mathrm{A}_{0}$ was the absorbance of the control (only $\mathrm{DPPH}$, without extract), $\mathrm{A}_{1}$ was the absorbance of the extract with $\mathrm{DPPH}$, and $\mathrm{A}_{2}$ was the absorbance of the extract without DPPH.

The antioxidant capacity of extract was expressed as the $50 \%$ inhibition of DPPH radicals $\left(\mathrm{IC}_{50} \mu \mathrm{g} / \mathrm{ml}\right.$ of extract). The $\mathrm{IC}_{50}$ of extract was calculated using a polynomial regression equation in which the abscissa represents the series of concentrations of extract and the ordinate represents the mean of the triplicate percentage of antioxidant activity at each concentration.

\section{Evaluation of the cytotoxic activity of the extracts}

The cytotoxic activity of the extracts was determined by using MTT assay [29, 35]. Human brain tumor cells (U251) and cervical cancer cells (HeLa) were cultured in RPMI 1640 medium and incubated under $5 \% \mathrm{CO}_{2}$ at $37{ }^{\circ} \mathrm{C}$ for $48 \mathrm{~h}$ to reach $80 \%$ confluence. The cells were harvested by gently scraping them with a cell scraper and re-suspended in a medium. From the suspension, $5 \times 10^{3}$ cells in $100 \mu \mathrm{l}$ of medium were dispensed into each well of a 96-well microtiter cell culture plate and incubated under the same conditions for $48 \mathrm{~h}$ to allow time for the adherence and growth of cells. The supernatant was gently aspirated, and $100 \mu \mathrm{l}$ of extracts were added with a range of four cytotoxic concentrations (100, 200, 400 and $800 \mu \mathrm{g} / \mathrm{ml}$ ) prepared in a medium and incubated for $24 \mathrm{~h}$. Ten microliter of $5 \mathrm{mg} / \mathrm{ml} \mathrm{MTT}$ was added to every well and the plate was reincubated for another $4 \mathrm{~h}$. The formazan crystals formed were dissolved in $100 \mu \mathrm{l}$ of DMSO. The plate was then read on a microplate reader (iMark ${ }^{\mathrm{nt}}$, BioRad) at $595 \mathrm{~nm}$. The number of dead cells per well was calculated as a percentage of the control, thereby measuring cell death after extract exposure. A doseresponse curve was plotted for each extract to calculate the $50 \%$ inhibition of cell growth $\left(\mathrm{IC}_{50} \mu \mathrm{g} / \mathrm{ml}\right.$ of extract). The cytotoxic capacities of extracts $\left(\mathrm{IC}_{50}\right)$ were calculated using a regression equation in which the abscissa represents the series of concentrations of extract and the ordinate represents the mean of the triplicate percentage of inhibition of cell growth.
Identification of the compounds in the extracts by GC-MS GC-MS analysis of the bioactive compounds in the different extracts of the stems of $D$. moniliforme was conducted using GCMS-QP2010 Ultra (Shimadzu Europa $\mathrm{GmbH}$, Germany) equipped with high-speed data acquisition and processing via advanced scan speed protocol. Spectroscopic detection by GC-MS involved an electron ionization system which utilized high-energy electrons $(70 \mathrm{eV})$. Pure helium gas $(99.99 \%)$ was used as the carrier gas with a column-flow rate of $0.95 \mathrm{ml} / \mathrm{min}$. The initial temperature was set at $100{ }^{\circ} \mathrm{C}$ and increased at the rate of $3{ }^{\circ} \mathrm{C} / \mathrm{min}$ after a holding time of about $10 \mathrm{~min}$. In the end, the temperature was increased to $300{ }^{\circ} \mathrm{C}$ at $10{ }^{\circ} \mathrm{C} / \mathrm{min}$. One microliter of $1 \%$ extract diluted with respective solvents was injected in a splitless mode. The relative quantity of the chemical compounds present in each of the extract was expressed as a percentage based on the peak area produced in the chromatogram. Bioactive compounds were identified based using GC retention times and by matching the spectra with standard values using computer software.

\section{Statistical analysis}

All data are expressed as a mean of three analyses. A linear regression model was applied to obtain equations for standards, gallic acid and quercetin. The total polyphenol and flavonoid contents were calculated by using linear equation of standards. The Duncan multiple-range test was applied to compare the significance differences of the total polyphenol and flavonoid contents in the extracts at $p \leq 0.05$. The $\mathrm{IC}_{50}$ values of the antioxidant and cytotoxic activities of the extracts were calculated by using an appropriate linear or non-linear regression equation obtained from the percentage activity of each extract at various concentrations with the F-statistic at $p \leq 0.05$. All the analysis was done using statistical software $\mathrm{R}$ version 3.1.2 [36].

\section{Results}

Plant extracts have significant amounts of total polyphenol and flavonoid contents

Total polyphenol contents (TPCs) in the extracts were calculated using the linear equation for standard gallic acid $\left(\mathrm{y}=0.0154 \mathrm{x}-0.3285 ; R^{2}=0.989 ; p=0.005\right)$ and total flavonoid contents (TFCs) was calculated using the linear equation for standard quercetin hydrate $(y=0.0242 x$ - 0.1845; $R^{2}=0.976 ; p=0.012$ ). The TPCs in the extracts ranged from 32.68 to $116.65 \mu \mathrm{g} \mathrm{GAE} / \mathrm{mg}$ of extract and TFCs from 54.13 to $116.67 \mu \mathrm{g}$ QE/mg of extract (Additional file 1). The TPC of DMC (116.65 $\mu \mathrm{g}$ $\mathrm{GAE} / \mathrm{mg}$ of extract) was much greater than those of other extracts. The TPCs of DME and DMA were the next highest respectively. The TFC of DMA (116.67 $\mu \mathrm{g}$ QE/mg of extract) was much higher than it was in other extracts, though the TFC of DME was also high (Fig. 1). The values 


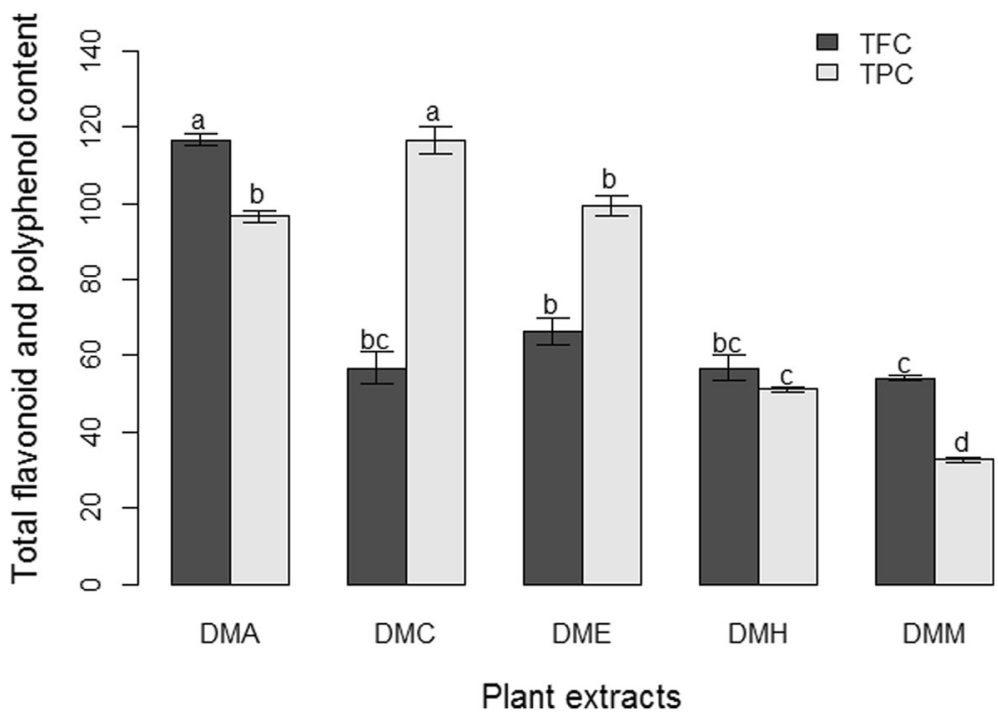

Fig. 1 Total polyphenol and flavonoid contents in crude extracts of $D$. moniliforme ( $n=3 ; p \leq 0.05$; values of the same letters are not statistically different)

of TPC and TFC in all the extracts were statistically significantly different at $p \leq 0.05$.

\section{Plant extracts showed the significant antioxidant activity by reducing DPPH radical}

The antioxidant activity of different extracts was determined by DPPH free-radical scavenging assay. The mean percentage of DPPH free-radical scavenging activity at different concentrations of extracts is shown in Fig. 2. DMH had the highest percentage of $\mathrm{DPPH}$ free-radical scavenging activity (94.48\%), followed by DME (94.45\%), DMC (94.35\%), and
DMA (93.71\%), and, considerably lower by DMM $(86.92 \%)$ at their $800 \mu \mathrm{g} / \mathrm{ml}$ concentration. The percentage of DPPH free-radical scavenging activity was measured at a range of concentrations from 50 to $800 \mu \mathrm{g} / \mathrm{ml}$ (Additional file 2). In all cases, it increased as the concentration increased. The antioxidant capacity of each extract was measured as the $\mathrm{IC}_{50}$ value of the extract, or in other words, the amount required to scavenge 50\% DPPH free-radicals. The antioxidant capacities of DMC, DMA, DMH and DME had much lower $\mathrm{IC}_{50}$ values $-42.39 \mu \mathrm{g} / \mathrm{ml}, 49.56 \mu \mathrm{g} / \mathrm{ml}$, $52.68 \mu \mathrm{g} / \mathrm{ml}$ and $58.77 \mu \mathrm{g} / \mathrm{ml}$ respectively than did DMM

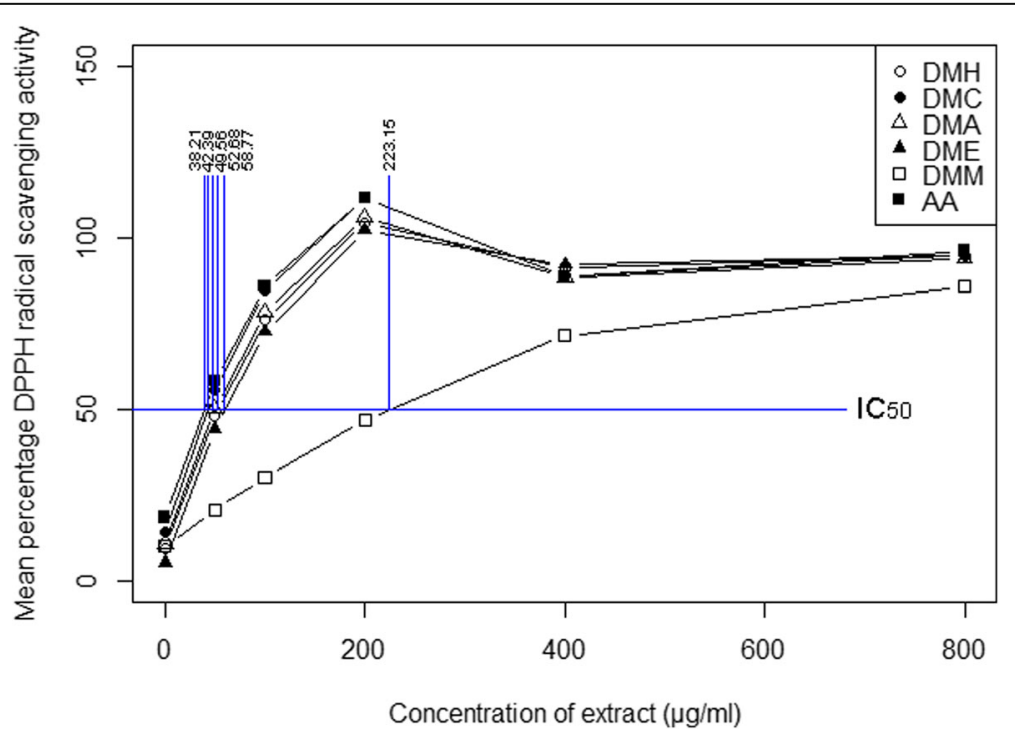

Fig. 2 Percentage of DPPH free-radical scavenging activity of crude extracts of D. moniliforme and ascorbic acid and their antioxidant capacities $(n=3 ; p \leq 0.05)$ 
(223.15 $\mu \mathrm{g} / \mathrm{ml})$. Except for DMM, the $\mathrm{IC}_{50}$ values of other extracts were statistically similar to the ascorbic acid (AA) , whose $\mathrm{IC}_{50}$ value was $38.21 \mu \mathrm{g} / \mathrm{ml}$ (Fig. 2).

\section{Plant extracts showed the significant cytotoxic activity against the HeLa and U251 cell lines}

The cytotoxic activity of extracts of $D$. moniliforme against the HeLa and U251 cell lines was determined using MTT colorometric assay. The mean percentage of the cytotoxic activity of extracts of different concentrations is shown in Fig. 3 (for HeLa cells) and in Fig. 4 (for U251 cells). The percentage of cell growth inhibition of extract-treated cells is increased as the concentration of the extract increased (Additional file 3 for HeLa cells and Additional file 4 for U251 cells). DMM at the concentration of $800 \mu \mathrm{g} / \mathrm{ml}$ showed the highest inhibition percentage of HeLa cells growth (78.68\%), while DME at the concentration of $800 \mu \mathrm{g} /$ $\mathrm{ml}$ had the highest cell growth inhibition of U251 cells (51.95\%). DME at $800 \mu \mathrm{g} / \mathrm{ml}$ showed moderate inhibition of the growth of HeLa cells (72.66\%) and DMM at $800 \mu \mathrm{g} / \mathrm{ml}$ showed moderate inhibition of the growth of U251 cells (39.93\%). The cytotoxic capacity of an extract was measured as its $\mathrm{IC}_{50}$ value, or the amount of extract required to inhibit the 50\% cell growth. The cytotoxic capacities of DMM and DME against HeLa cells were $155.80 \mu \mathrm{g} / \mathrm{ml}$ and $181.93 \mu \mathrm{g} /$ $\mathrm{ml}$ of extract respectively (Fig. 3). Their cytotoxic capacities were statistically significantly different from those of other extracts. In terms of inhibiting the growth of U251 cells, the cytotoxic capacity of DME was $772.50 \mu \mathrm{g} / \mathrm{ml}$ of extract, but neither $\mathrm{DMH}, \mathrm{DMC}$ nor DMA showed any such capacity (Fig. 4).
Plant extracts have phenol derivatives detected by GC-MS The bioactive compounds present in the hexane, chloroform, acetone, ethanol and methanol extracts obtained from D. moniliforme stems were detected using gas chromatography (GC) and identified through mass spectrometry (MS). The compounds detected and identified in DME and DMM are shown in Tables 1 and 2. The results of the GC-MS analysis of the other extracts are not shown here because those extracts showed either no or little cytotoxic activity. The elution time of compounds with their base mass-to-charge ratio $(\mathrm{m} / \mathrm{z})$ and their contents by percentage were also determined. Based on abundance, two major compounds dimethylsulfoxonium formylmethylide (37.99\%) and 2,3-dihydro-3,5dihydroxy-6-methyl-4H-pyran-4-one (21.41\%) were detected and identified in DMM and two, 5-(hydroxymethyl)-2-furancarboxaldehyde (45.59\%) and 2,3-dihydro-3,5-dihydroxy-6-methyl-4H-pyran-4-one (16.74\%) in DME. Both DME and DMM had a number of other phenol derivatives too including tetrahydro-1,1-dioxide-thiophene-3-ol, $\gamma$-sitosterol, 2methoxy-4-vinylphenol, 2,6-dimethoxy-phenol, 2,6dimethoxy-4-(2-propenyl)-phenol, n-nonadecanol-1, 1-heptacosanol and stigmast-5-en-3-ol. The GC chromatogram of DMM and DME are presented in Additional files 5 and 6 respectively.

\section{Discussion}

The results showed that variations in the TPC and TFC of different extracts are affected by the polarity of the solvent used and the nature of the phytochemicals dissolved. The fact that extraction solvents

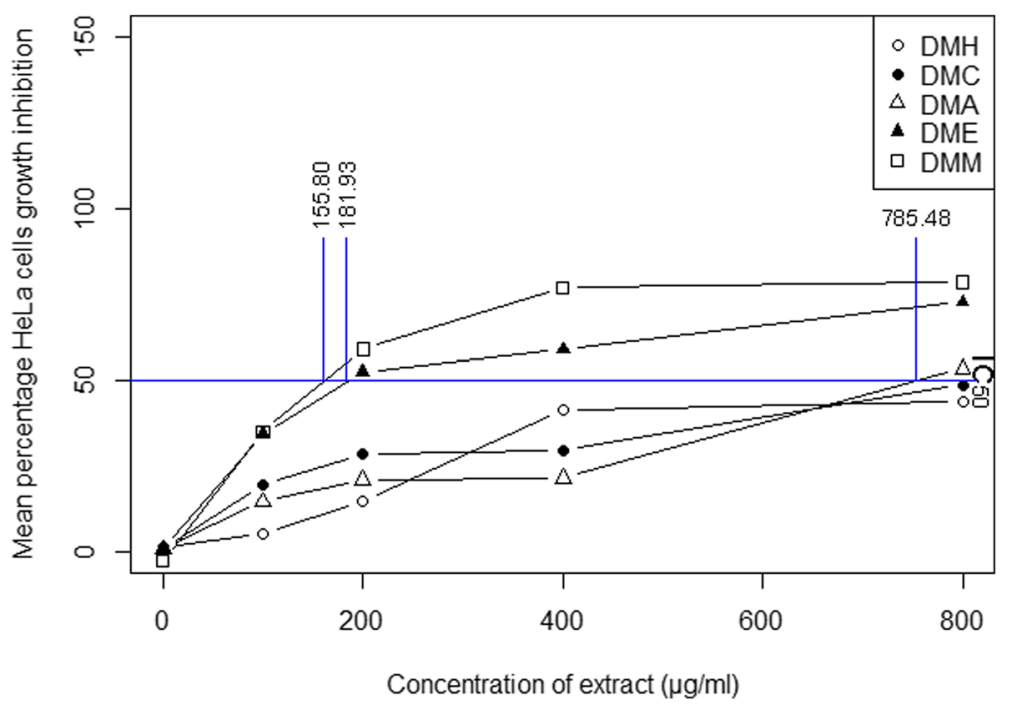

Fig. 3 Percentage of cell growth inhibition of the HeLa cell line by crude extracts of D. moniliforme and their cytotoxic capacities $(n=3 ; p \leq 0.05)$ 


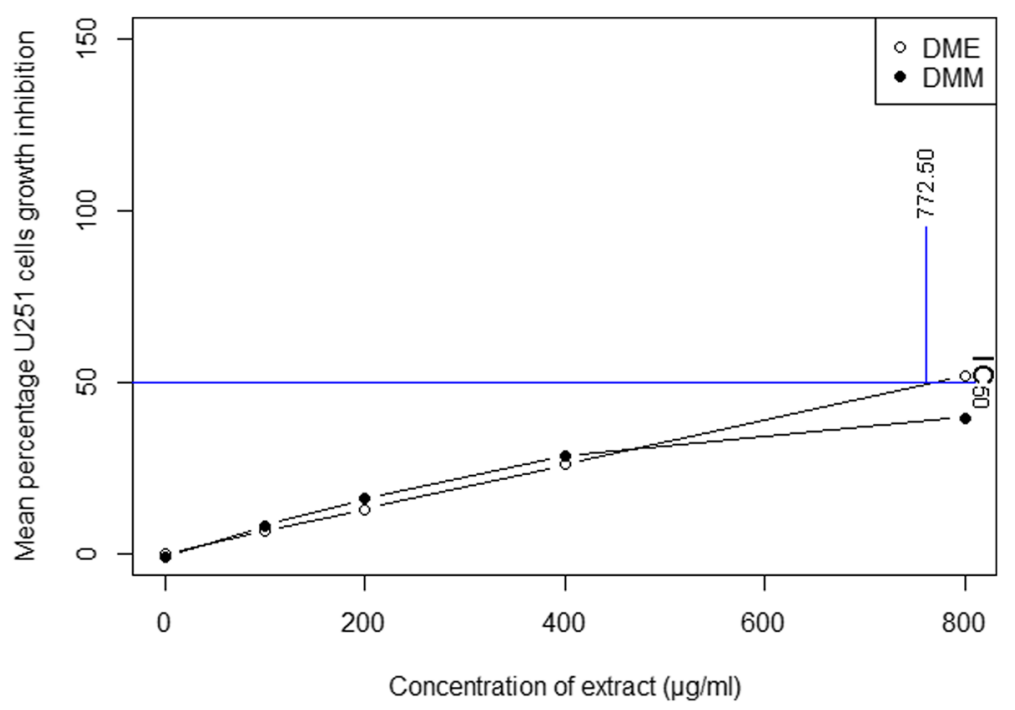

Fig. 4 Percentage of cell growth inhibition of the U251 cell line by crude extracts of $D$. moniliforme and their cytotoxic capacities $(n=3 ; p \leq 0.05)$

with different polarities extract varying amounts of polyphenol and flavonoid compounds from plants is well known [37-40]. This study used a range of extraction solvents, from those with low polarity to those with high polarity, in order to dissolve phytochemicals with similar polarities. The hexane extract $(\mathrm{DMH})$ obtained from using hexane, a low-polarity solvent, had little TPC or TFC because it has very few phytochemicals derived from either polyphenol or flavonoid groups. In contrast, both chloroform and acetone extracts exhibited high TPC and TFC, probably because these extracts contain many compounds of polyphenol and flavonoid groups with polarities similar to those of chloroform and acetone. Previous

Table 1 Bioactive compounds detected in D. moniliforme ethanol extract (DME)

\begin{tabular}{|c|c|c|c|c|}
\hline S.N. & Compound Name & RT (min) & Content (\%) & Base $\mathrm{m} / \mathrm{z}$ \\
\hline 1 & Dimethylsulfoxonium formylmethylide & 4.043 & 4.50 & 63.00 \\
\hline 2 & 4H-Pyran-4-one, 2,3-dihydro-3,5-dihydroxy-6-methyl- & 4.142 & 16.74 & 43.00 \\
\hline 3 & 3-Cyclohexene-1-methanol,.alpha.,alpha.,4-trimethyl-,(S)- & 4.307 & 2.51 & 59.05 \\
\hline 4 & 3(2H)-Furanone, 4-methoxy-2,5-dimethyl- & 4.367 & 3.95 & 43.00 \\
\hline 5 & Thiophene-3-ol, tetrahydro-, 1,1-dioxide & 4.410 & 3.17 & 44.00 \\
\hline 6 & 5-Acetoxymethyl-2-furaldehyde & 4.480 & 4.52 & 126.10 \\
\hline 7 & 2-Furancarboxaldehyde, 5-(hydroxymethyl)- & 4.754 & 45.59 & 97.05 \\
\hline 8 & 5-Acetoxymethyl-2-furaldehyde & 5.010 & 2.66 & 126.10 \\
\hline 9 & 2-Methoxy-4-vinylphenol & 5.131 & 2.61 & 150.20 \\
\hline 10 & Phenol, 2,6-dimethoxy- & 5.371 & 2.70 & 154.20 \\
\hline 11 & 4-Methyl-2,5-dimethoxybenzaldehyde & 6.991 & 2.75 & 180.15 \\
\hline 12 & Cinnamic acid, 4-hydroxy-3-methoxy-, & 7.103 & 0.96 & 149.15 \\
\hline 13 & Phenol, 2,6-dimethoxy-4-(2-propenyl)- & 7.994 & 0.83 & 194.15 \\
\hline 14 & 4-((1E)-3-Hydroxy-1-propenyl)-2-methoxyphenol & 8.414 & 1.19 & 137.15 \\
\hline 15 & Pentadecanoic acid & 9.688 & 0.76 & 43.05 \\
\hline 16 & Methyl (3,4-dimethoxyphenyl)(hydroxy) acetate & 9.970 & 1.01 & 167.15 \\
\hline 17 & Benzenemethanol, 2,5-dimethoxy-, acetate & 10.128 & 0.96 & 210.15 \\
\hline 18 & Bis[(4-methoxyphenyl)methyl]disulfide & 12.852 & 1.34 & 121.15 \\
\hline 19 & Tetradecanal & 13.308 & 0.67 & 57.10 \\
\hline 20 & gamma.-Sitosterol & 21.005 & 0.60 & 43.05 \\
\hline
\end{tabular}


Table 2 Bioactive compounds detected in D. moniliforme methanol extract (DMM)

\begin{tabular}{|c|c|c|c|c|}
\hline S.N. & Compound Name & RT (min) & Content (\%) & Base $\mathrm{m} / \mathrm{z}$ \\
\hline 1 & Dimethylsulfoxonium formylmethylide & 4.081 & 37.99 & 63.00 \\
\hline 2 & Methoxyacetic acid, 2-pentyl ester & 4.217 & 7.74 & 43.00 \\
\hline 3 & 4H-Pyran-4-one, 2,3-dihydro-3,5-dihydroxy-6-methyl- & 4.303 & 21.41 & 43.00 \\
\hline 4 & 3-Cyclohexene-1-methanol,.alpha.,alpha.,4-trimethyl-,(S)- & 4.481 & 9.62 & 61.00 \\
\hline 5 & Dimethylsulfoxonium formylmethylide & 4.557 & 3.01 & 78.00 \\
\hline 6 & 2-Furancarboxaldehyde, 5-(hydroxymethyl)- & 4.686 & 6.41 & 97.05 \\
\hline 7 & 2-Methoxy-4-vinylphenol & 5.199 & 0.39 & 150.15 \\
\hline 8 & Phenol, 2,6-dimethoxy- & 5.411 & 0.58 & 154.15 \\
\hline 9 & 3',5'-Dimethoxyacetophenone & 6.961 & 0.90 & 180.15 \\
\hline 10 & Diethyl Phthalate & 7.089 & 0.29 & 149.10 \\
\hline 11 & Phenol, 2,6-dimethoxy-4-(2-propenyl)- & 7.980 & 0.31 & 194.10 \\
\hline 12 & 1,2-Benzenedicarboxylic acid, bis(2-methylpropyl) ester & 9.064 & 7.11 & 149.10 \\
\hline 13 & Octatriacontyl pentafluoropropionate & 13.036 & 0.74 & 57.05 \\
\hline 14 & Heneicosane & 14.459 & 0.29 & 57.10 \\
\hline 15 & n-Nonadecanol-1 & 14.510 & 0.70 & 83.10 \\
\hline 16 & Cyclononasiloxane, octadecamethyl- & 15.101 & 0.19 & 73.05 \\
\hline 17 & 1-Heptacosanol & 15.957 & 0.65 & 57.10 \\
\hline 18 & 1-Heptacosanol & 17.667 & 0.49 & 97.10 \\
\hline 19 & Stigmast-5-en-3-ol, oleate & 18.154 & 0.31 & 97.10 \\
\hline 20 & gamma.-Sitosterol & 20.976 & 0.85 & 43.05 \\
\hline
\end{tabular}

research on the extraction of differing flavonoid and polyphenol contents and compounds in different solvents in various Dendrobium species supports the present research [37, 41-44]. The types of compounds we identified in D. moniliforme in this study were similar to those identified in this plant in previous studies [10-15].

The antioxidant potential of each extract was measured using the change in its absorbance of decolourized DPPH free-radicals as it accepts electrons from the antioxidant-rich compounds. Previous research found that phenol derivatives have the ability to reduce and decolourize DPPH free-radicals [45-47]. The fact that the antioxidant activity of the extracts has a strong relationship with the solvent employed is mainly due to the fact that compounds with antioxidant potential dissolve differentially in solvents with different polarities [37, 48]. Natural antioxidants present in plants inhibit the deleterious consequences of oxidative stress. In particular, the literature reports that the polyphenol and flavonoid contents of extracts of the Dendrobium species exhibit antioxidant activity [41, 44, 49-51]. For example, bibenzyl derivatives isolated from $D$. moniliforme showed antioxidant activity [11, 13, 14]. This study found that the antioxidant potential of four extracts of D. moniliforme is due to the presence of antioxidant-rich compounds like phenol derivatives.
Free-radicals and reactive oxygen species induce the carcinogenesis of human cells that causes cancer [16]. Antioxidant-rich compounds in food products, in contrast, scavenge free-radicals and prevent the radical chain reaction of oxidation, thereby delaying or inhibiting the oxidation process. The antioxidant effect of phenol derivatives accounts for their cancer chemo-preventive and therapeutic effects [52]. The mechanisms which phenol derivatives use to inhibit cancer, arresting the cell cycle and inducing apoptosis is described in study of the anticancer activity of $D$. moniliforme [53, 54]. This study found that both methanol and ethanol extracts were cytotoxic against the HeLa and U251 cell lines. These both extracts have many phenol derivatives capable of reducing the number of free radicals and inhibiting oxidation. The several phenol derivatives detected in these extracts arrest the cell cycle and induce apoptosis through morphological changes like cell shrinkage, chromatin condensation, and nuclear fragmentation $[28,55,56]$, thereby serving as an important defense mechanism preventing the proliferation of cancer cells. Like other studies of the anticancer activities of Dendrobium species [21-27], this study too, found that phenol derivatives induces the apoptosis of cancer cells. Phenol derivatives of extracts do exhibit both antioxidant and anticancer effects $[2-4,57]$. 


\section{Conclusions}

D. moniliforme extracts contain a number of bioactive compounds which exhibit both antioxidant and cytotoxic activities against free radicals and cancer cell lines respectively. This result suggests that this plant has potential pharmacological importance.

\section{Additional files}

Additional file 1: Total polyphenol or flavonoid contents in the plant extracts of D. moniliforme (triplicate data). (DOCX $12 \mathrm{~kb}$ )

Additional file 2: Percentage of DPPH free-radical scavenging activity by plant extracts of $D$. moniliforme (triplicate data). (DOCX $12 \mathrm{~kb}$ )

Additional file 3: Percentage of HeLa cell growth inhibition by plant extracts of D. moniliforme (triplicate data). (DOCX $12 \mathrm{~kb}$ )

Additional file 4: Percentage of U251 cell growth inhibition by plant extracts of D. moniliforme (triplicate data). (DOCX $11 \mathrm{~kb}$ )

Additional file 5: Chromatogram of $D$. moniliforme methanol extract (DMM). (DOCX $142 \mathrm{~kb})$

Additional file 6: Chromatogram of D. moniliforme ethanol extract (DME). (DOCX $143 \mathrm{~kb})$

\section{Abbreviations}

AA: Ascorbic acid; DMA: Dendrobium moniliforme acetone extract; DMC: Dendrobium moniliforme choloroform extract; DME: Dendrobium moniliforme ethanol extract; DMH: Dendrobium moniliforme hexane extract; DMM: Dendrobium moniliforme methanol extract; DPPH: 2,2-diphenyl-1-picrylhydrazyl; MTT: 3-(4,5dimethylthiazol-2-yl)-2,5-diphenyltetrazolium bromide; TFC: Total flavonoid content; TPC: Total polyphenol content

\section{Acknowledgments}

We are thankful to the Department of Neurosurgery of Kagoshima University, Japan, for providing us with U251 cell lines and to Everest Biotech Pvt. Ltd., Nepal for providing us with HeLa cell lines.

\section{Funding}

The university grants commission (UGC) of Nepal provided a partial grant for this research but played no role in the design of the study, the collection, analysis or interpretation of data, or the writing of this manuscript.

\section{Availability of data and materials}

All data generated or analysed during this study are included in this published article [supplementary information files].

\section{Authors' contributions \\ MRP did all the laboratory work, analyzed and interpreted the data, and prepared and finalized the manuscript. MBC did the laboratory work and reviewed the manuscript. BP managed the U251 cell lines and reviewed the manuscript. BP designed the research and reviewed the manuscript. All authors have read and approved the manuscript.}

Ethics approval and consent to participate

Not applicable.

\section{Competing interests}

The authors declare that they have no competing interests.

\section{Publisher's Note}

Springer Nature remains neutral with regard to jurisdictional claims in published maps and institutional affiliations.

\section{Author details}

'Central Department of Botany, Tribhuvan University, Kirtipur, Kathmandu, Nepal. ${ }^{2}$ Annapurna Research Center, Kathmandu, Nepal.
Received: 21 February 2018 Accepted: 10 April 2018

Published online: 23 April 2018

\section{References}

1. Rajbhandari KR. Orchids of Nepal: Status, threat and conservation. Proc. Natl. Work. NTFP/MAPs sect. Action plant dev. Orchid. Department of Plant Resources, Ministry of Forest and Soil Conservation and central Department of Botany. Kathmandu, Nepal: Tribhuvan university; 2014. p. 1-40.

2. Ng TB, Liu J, Wong JH, Ye X, Sze SCW, Tong Y, et al. Review of research on Dendrobium, a prized folk medicine. Appl Microbiol Biotechnol. 2012;93:1795-803.

3. Lam Y, Ng TB, Yao RM, Shi J, Xu K, Sze SCW, et al. Evaluation of chemical constituents and important mechanism of pharmacological biology in Dendrobium plants. Evidence-based Complement Altern Med. 2015;2015:25.

4. Xu J, Han QB, Li SL, Chen XJ, Wang XN, Zhao ZZ, et al. Chemistry, bioactivity and quality control of Dendrobium, a commonly used tonic herb in traditional Chinese medicine. Phytochem Rev. 2013;12:341-67.

5. Pant B. Medicinal orchids and their uses: tissue culture a potential alternative for conservation. African J Plant Sci. 2013;7:448-67.

6. Pant B, Paudel MR, Chand MB, Wagner SH. A treasure trove of orchids in Central Nepal. Kirtipur, Kathmandu, Nepal: Central Department of Botany, Tribhuvan University; 2016

7. Zhao P, Wu F, Feng FS, Wang WJ. Protocorm-like body (PLB) formation and plant regeneration from the callus culture of Dendrobium candidum wall ex Lindl. Vitr Cell Dev Biol - Plant. 2008;44:178-85.

8. Zheng YP, Jiang W, Liao FL, Lu HF. Optimization of light quality for production of alkaloid and polysaccharide in Dendrobium candidum wall. Ex Lindl. J. Med. Plants Res. 2012;6:560-5.

9. Meng LZ, Lv GP, Hu DJ, Cheong KL, Xie J, Zhao J, et al. Effects of polysaccharides from different species of Dendrobium (Shihu) on macrophage function. Molecules. 2013;18:5779-91.

10. Bi ZM, Wang ZT, Xu LS. Chemical Constituents of Dendrobium moniliforme. Acta Bot Sin. 2004:46:124-6.

11. Li Y, Wang CL, Wang YJ, Guo SX, Yang JS, Chen XM, et al. Four new bibenzyl derivatives from Dendrobium candidum. Chem. Pharm. Bull. 2009:57(9):997.

12. Li Y, Wang CL, Guo SX, Yang JS, Xiao PG. Two new compounds from Dendrobium candidum. Chem. Pharm. Bull. 2008:56:1477-9.

13. Li Y, Wang CL, Zhao HJ, Guo SX. Eight new bibenzyl derivatives from Dendrobium candidum. J Asian Nat Prod Res. 2014;16:1035-43.

14. Li Y, Wang CL, Wang YJ, Guo SX, Yang JS, Chen XM, et al. Three new bibenzyl derivatives from Dendrobium candidum. Chem Pharm Bull. 2009:57:218-9.

15. Zhao C, Liu Q, Halaweish F, Shao B, Ye Y, Zhao W. Copacamphane, picrotoxane, and alloaromadendrane sesquiterpene glycosides and phenolic glycosides from Dendrobium moniliforme. J Nat Prod. 2003;66:1140-3.

16. Salman KA, Ashraf S. Reactive oxygen species: a link between chronic inflammation and cancer. Asia-Pacific J. Mol. Biol. Biotechnol. 2013:21:41-9.

17. Roy N, Laskar RA, Sk I, Kumari D, Ghosh T, Begum NA. A detailed study on the antioxidant activity of the stem bark of Dalbergia sissoo Roxb., an Indian medicinal plant. Food Chem. 2011;126:1115-21.

18. Fu L, Xu BT, Xu XR, Gan RY, Zhang Y, Xia EQ, et al. Antioxidant capacities and total phenolic contents of 62 fruits. Food Chem. 2011;129:345-50

19. Mensor LL, Menezes FS, Leitao GG, Reis AS, dos Santos TC, Coube CS, et al. Screening of Brazilian plant extracts for antioxidant activity by the use of DPPH free radical method. Phyther Res. 2001;15:127-30.

20. RMP G. Orchids: Orchids: A review of uses in traditional medicine, its phytochemistry and pharmacology. J Med Plants Res. 2010;4:592-638.

21. Bao L, Wang JH, Luo JP. Inhibitory effects of water extracts from four species of dendrobiums on HelaS3 cells and HepG2 cells. J. Anhui Agric Sci. 2008:36:15968-70.

22. Lee MJ, Jung HK, Kim MS, Jang JH, Sim MO, Kim TM, et al. Acute toxicity and cytotoxicity evaluation of Dendrobium moniliforme aqueous extract in vivo and in vitro. Lab Anim Res. 2016;32:144-50.

23. Wang Q, Sun P, Li G, Zhu K, Wang C, Zhao X. Inhibitory effects of Dendrobium candidum wall ex Lindl. On azoxymethane- and dextran sulfate sodiuminduced colon carcinogenesis in C57BL/6 mice. Oncol Lett. 2014;7:493-8.

24. Li G, Sun P, Wang Q, Qian Y, Zhu K, Zhao X. Dendrobium candidum wall. Ex Lindl. Attenuates CCl4-induced hepatic damage in imprinting control region mice. Exp Ther Med. 2014;8:1015-21.

25. Li G, Sun P, Zhou Y, Zhao X, Chen F. Preventive effects of Dendrobium candidum wall ex Lindl. On the formation of lung metastases in BALB/c mice injected with 26-M3.1 colon carcinoma cells. Oncol Lett. 2014;8:1879-85. 
26. Zhao X, Sun P, Qian Y, Suo H. D. Candidum has in vitro anticancer effects in HCT-116 cancer cells and exerts in vivo anti-metastatic effects in mice. Nutr Res Pract. 2014:8:487-93.

27. Sun J, Guo Y, Fu X, Wang Y, Liu Y, Huo B, et al. Dendrobium candidum inhibits MCF-7 cells proliferation by inducing cell cycle arrest at G2/M phase and regulating key biomarkers. Onco. Targets Ther. 2016;9:21-30.

28. Lowe SW, Lin AW. Apoptosis in cancer. Carcinogenesis. 2000;21:485-95.

29. Mosmann T. Rapid colorimetric assay for cellular growth and survival: application to proliferation and cytotoxicity assays. J Immunol Methods. 1983:65:55-63.

30. Casuga FP, Castillo AL, Corpuz MJAT. GC-MS analysis of bioactive compounds present in different extracts of an endemic plant Broussonetia luzonica (Blanco) (Moraceae) leaves. Asian Pac J Trop Biomed Elsevier BV. 2016;6:957-61

31. Kanthal LK, Dey A, Satyavathi K, Bhojaraju P. GC-MS analysis of bio-active compounds in methanolic extract of Lactuca runcinata DC. Pharm Res. 2014:6:58-61.

32. Jones WP, Kinghorn AD. Extraction of plant secondary metabolites. In: Sarker SD, Latif Z, Gray Al, editors. Methods Biotechnol. Nat. Prod. Isol. Second Edi. Totowa, NJ: Humana press Inc; 2005. p. 323-51.

33. Stankovic MS. Total phenolic content, flavonoid concentration and antioxidant activity of Marrubium peregrinum L. extracts. Kragujev. J Sci. 2011;33:63-72

34. Zhao GR, Xiang ZJ, Ye TX, Yuan YJ, Guo ZX. Antioxidant activities of Salvia miltiorrhiza and Panax notoginseng. Food Chem. 2006;99:767-74.

35. Sargent JM, Taylor CG. Appraisal of the MTT assay as a rapid test of chemosensitivity in acute myeloid leukaemia. Br J Cancer. 1989;60:206-10.

36. core team R. R: a language and environment for statistical computing. Vienna, Austria: R foundation for statistical computing; 2016.

37. Boeing JS, Barizão ÉO, e Silva BC, Montanher PF, de Cinque Almeida V, Visentainer JV. Evaluation of solvent effect on the extraction of phenolic compounds and antioxidant capacities from the berries: application of principal component analysis. Chem Cent J. 2014;8:48.

38. Złotek U, Mikulska S, Nagajek M, Świeca M. The effect of different solvents and number of extraction steps on the polyphenol content and antioxidant capacity of basil leaves (Ocimum basilicum L.) extracts. Saudi J Biol Sci. 2016;23:628-33.

39. Dhanani T, Shah S, Gajbhiye NA, Kumar S. Effect of extraction methods on yield, phytochemical constituents and antioxidant activity of Withania somnifera. Arab J Chem King Saud University. 2017;10:S1193-9.

40. Do QD, Angkawijaya AE, Ngyyen PL, Huynh LH, Soetaredjo FE, Ismadji S, et al. Effect of extraction solvent on total phenol content, total flavonoid content, and antioxidant activity of Limnophila aromatica. J Food Drug Anal. 2014;22:296-302.

41. Paudel MR, Chand MB, Pant B, Pant B. Cytotoxic activity of antioxidantRiched Dendrobium longicornu. Pharmacogn J. 2017;9:499-503.

42. Chand MB, Paudel MR, Pant B. The antioxidant activity of selected wild orchids of Nepal. J Coast Life Med. 2016:4:731-6.

43. Saeed N, Khan MR, Shabbir M. Antioxidant activity, total phenolic and total flavonoid contents of whole plant extracts Torilis leptophylla L. BMC Complement Altern Med. 2012;12:221.

44. Paudel MR, Chand MB, Karki N, Pant B. Antioxidant activity and total phenolic and flavonoid contents of Dendrobium amoenum wall. Ex Lindl. Bot. Orient. J Plant Sci. 2015;9:20-6.

45. Tiveron AP, Melo PS, Bergamaschi KB, Vieira TMFS, Regitano-d'Arce MAB, Alencar SM. Antioxidant activity of Brazilian vegetables and its relation with phenolic composition. Int J Mol Sci. 2012;13:8943-57.

46. Ozgen M, Reese RN, Tulio AZ, Scheerens JC, Miller AR. Modified 2,2-azinobis-3-ethylbenzothiazoline-6-sulfonic acid (ABTS) method to measure antioxidant capacity of selected small fruits and comparison to ferric reducing antioxidant power (FRAP) and 2,2'-diphenyl-1- picrylhydrazyl (DPPH) methods. J Agric Food Chem. 2006;54:1151-7.

47. Huang D, Ou B, Prior RL. The chemistry behind antioxidant capacity assays. J Agric Food Chem. 2005;53:1841-56.

48. Dent M, Dragovic V, Penic M, Brncic M, Bosiljkov T, Levaj B. The effect of extraction solvents, temperature and time on the composition and mass fraction of polyphenols in Dalmatian wild sage (Salvia officinalis L.) extracts. Food Technol Biotechnol. 2013;51:84-91.

49. Mukherjee S, Pathak D, Parikh J, Jagtap S, Shaikh S, Tupe R. Antiglycation and antioxidant activity of a rare medicinal orchid Dendrobium aqueum Lindl. Med Chem Drug Discov. 2012;2:17-29.
50. Moretti M, Cossignani L, Messina F, Dominici L, Villarini M, Curini M, et al. Antigenotoxic effect, composition and antioxidant activity of Dendrobium speciosum. Food Chem. 2013;140:660-5.

51. Chimsook T. Phytochemical screening, Total phenolic content, antioxidant activities and cytotoxicity of Dendrobium signatum leaves. MATEC Web Conf. 2016;62:3005.

52. Dai J, Mumper RJ. Plant phenolics: extraction, analysis and their antioxidant and anticancer properties. Molecules. 2010;15:7313-52.

53. Darwiche N, El-banna S, Gali-muhtasib H. Cell cycle modulatory and apoptotic effects of plant-derived anticancer drugs in clinical use or development. Expert Opin Drug Discov. 2007;2:361-79.

54. Gali-Muhtasib H, Hmadi R, Kareh M, Tohme R, Darwiche N. Cell death mechanisms of plant-derived anticancer drugs: beyond apoptosis. Apoptosis. 2015;20:1531-62.

55. Elmore S. Apoptosis: a review of programmed cell death. Toxicol Pathol. 2007;35:495-516.

56. Ko EY, Moon A. Natural products for chemoprevention of breast Cancer. J Cancer Prev. 2015;20:223-31.

57. Cai Y, Luo Q, Sun M, Corke H. Antioxidant activity and phenolic compounds of 112 traditional Chinese medicinal plants associated with anticancer. Life Sci. 2004;74:2157-84

\section{Ready to submit your research? Choose BMC and benefit from:}

- fast, convenient online submission

- thorough peer review by experienced researchers in your field

- rapid publication on acceptance

- support for research data, including large and complex data types

- gold Open Access which fosters wider collaboration and increased citations

- maximum visibility for your research: over $100 \mathrm{M}$ website views per year

At $B M C$, research is always in progress.

Learn more biomedcentral.com/submissions 